ADAM MIODOWSKI (Białystok)

\title{
GENEZA UKSZTA ŁTOWANIA SIE NEGATYWNEGO STANOWISKA WYCHODŹCZYCH UGRUPOWAŃ DEMOKRATYCZNYCH WOBEC IDEI POLSKIEGO WOJSKA W ROSJI
}

Po utworzeniu Tymczasowej Rady Stanu [dalej: TRS], piotrogrodzki odłam polskich demokratów ${ }^{1}$ skupiony w Polskim Zrzeszeniu Niepodległościowym [dalej: PZN] uznał natychmiast powołany przez państwa centralne organ przedstawicielski za rząd powstającego państwa polskiego. Już w styczniu 1917 r. PZN skierowało do Warszawy poufny memoriał, w którym zaprezentowało się jako organizacja działająca na terenie całego państwa rosyjskiego, posiadająca duży wpływ na rosyjską opinię publiczną, zwalczająca rusofilstwo wśród wychodźstwa polskiego i przygotowująca się do zdecydowanego postawienia sprawy niepodległości Polski - nie tylko na gruncie rosyjskim, lecz również międzynarodowym. Poza tym przywoływany memoriał zawierał stwierdzenie, że obowiązkiem każdego Polaka i każdej polskiej organizacji jest oddać się na rozkazy TRS, która od chwili ukonstytuowa-

1 Prapoczątki zorganizowanego funkcjonowania polskich ugrupowań demokratycznych w Rosji sięgają schyłku 1915 r., kiedy to z inicjatywy Aleksandra Więckowskiego i Aleksandra Babiańskiego utworzono w Piotrogrodzie konspiracyjne Polskie Zrzeszenie Niepodległościowe. Rewolucja lutowa zapoczątkowała jakościowo nowy etap organizowania się polskich ugrupowań demokratycznych w Rosji. Powstawały one w tych ośrodkach miejskich, gdzie skupiska społeczności polskiej były najliczniejsze. Najważniejszym pośród nich był Piotrogród, w którym od połowy marca 1917 r. działał stworzony na bazie Polskiego Zrzeszenia Niepodległościowego, Polski Komitet Demokratyczny. Drugim co do znaczenia ośrodkiem pozostawała Moskwa, gdzie 30.03.1917 r. zorganizował się Polski Klub Demokratyczny. Spośród struktur prowincjonalnych do najważniejszych należały: działający od kwietnia 1917 r. w Mińsku Polski Związek Demokratyczny; powołany w Kijowie 26.03.1917 r. Związek Demokratyczny na Rusi; oraz powstały na przełomie kwietnia i maja tegoż roku w Charkowie Polski Klub Demokratyczny. 
nia się staje się rządem polskim. Demokraci w swym wiernopoddańczym memoriale, będącym swego rodzaju akcesem do obozu aktywistycznego, nie poprzestali jednak na tych deklaracjach. Opowiedzieli się bowiem wzorem TRS za ustrojem monarchicznym, głosząc że „Król polski zdaje nam się być pożądanym jak najrychlej symbolem, który by kres położył wahaniom ostatecznie i sprawie naszej nadał majestat i kształt najpożądańszy" "2. Powyższe oświadczenie wiązało się zapewne $z$ niezwykłym poświęceniem, gdyż jego treść kolidowała przecież $\mathrm{z}$ wyznawanym przez środowisko demokratyczne republikanizmem.

Nieco inaczej przedstawiała się natomiast sprawa przejścia Aleksandra Lednickiego i związanego $\mathrm{z}$ nim moskiewskiego ośrodka demokratycznego na pozycje aktywistyczne. Jeszcze pod koniec 1916 r. środowisko to ustami swego lidera wyrażało negatywne opinie na temat aktu 5 listopada, deklarując m.in. swoją wierność Rosji i podważając prawomocność manifestu dwóch cesarzy. Tym niemniej, obok tych wiernopoddańczych deklaracji pojawił się też i zwiastun mającego się w niedalekiej przyszłości dokonać przewartościowania dotychczasowej orientacji. A. Lednicki uznawał bowiem ogłoszoną w listopadowym manifeście niepodległość Królestwa Polskiego za fakt dokonany. Nie zadowalało go co prawda ograniczenie terytorium odrodzonego państwa do granic Kongresówki, bo jak stwierdzał „(...) żadnego Polaka nie zadowoli państwo polskie, do którego nie należy ani Galicja, ani Poznańskie, a także Śląsk jeden i drugi (...) i ujście do morza" 3. Pomimo tych obiekcji przyznawał również, że akt 5 listopada posiada dla Polski dużą wartość realną. Dzięki temu wedle jego opinii „(...) kraj będzie mógł się organizować politycznie (...), będzie mógł stworzyć przedstawicielstwo, które gdy nadejdzie chwila pokoju, wespół z przedstawicielami innych narodów Europy będzie mogło wziąć udział w obradach nad ostatecznymi warunkami pokoju i przymierza" 4 .

A. Lednicki po objęciu stanowiska prezesa Komisji Likwidacyjnej do Spraw Królestwa Polskiego [dalej: KLdSKP], już w swym pierwszym wystąpieniu na inauguracyjnym posiedzeniu tego organu 15 kwietnia $1917 \mathrm{r}$.

2 Archiwum Państwowe w Krakowie. Naczelny Komitet Narodowy [dalej: APK NKN], t. XLIV, k. 539-543; I. Spustek, Polacy w Piotrogrodzie 1914-1917, Warszawa 1966, s. 379.

3 A. Lednicki, Artykuty, listy, przemówienia (1915-1918), Warszawa 1921, s. 142-147 .

4 P. Milukow, Aleksander Lednicki jako rzecznik polsko-rosyjskiego porozumienia, Warszawa 1939, s. 34 . 
wyraził opinię, że „Naród i Polska są tam na ziemi ojczystej (...) i tylko tam powołanemu rządowi przysługuje prawo reprezentacji narodowej" ${ }^{5}$. Była to niezwykle ważna deklaracja, która zdeterminować miała całą jego późniejszą działalność polityczną. Tą wypowiedzią uznającą autorytet TRS, prezes KLdSKP faktycznie zgłaszał swój akces do obozu aktywistycznego. Od tej chwili stawał się obok A. Więckowskiego jednym z przywódców tej orientacji na gruncie rosyjskim.

Z czasem za werbalnymi deklaracjami pojawiły się też i konkretne przejawy współpracy. A. Lednicki zdecydował się posłużyć w tym celu kierowaną przez siebie instytucją. Pomiędzy KLdSKP i TRS nawiązane zostały tzw. robocze kontakty, które początkowo ograniczyć się miały do spraw humanitarnych i gospodarczych. W celu ułatwienia wzajemnych kontaktów A. Lednicki zdecydował się stworzyć w stolicy neutralnej Szwecji rezydenturę KLdSKP. W sierpniu 1917 r. placówkę tę objął Józef Ziabicki, demokrata o zdecydowanie aktywistycznej orientacji ${ }^{6}$.

Niebagatelną rolę w ukształtowaniu się tak silnych powiązań demokratów z obozem aktywistycznym w Kraju odegrała anarchizacja życia społeczno-politycznego w Rosji. Panujące nad Newą po lutowym przewrocie rewolucyjnym stosunki umożliwiły demokratom przyjęcie postawy balansowania pomiędzy rządem państwa prowadzącego wojnę z Niemcami, a TRS będącą przecież tworem niemieckim. Demokraci, korzystając więc z dobrej koniunktury na gruncie rosyjskim, dla nawiązania kontaktów z aktywistami w Kraju zdecydowani byli własne związki z nimi jeszcze bardziej zacieśnić. W Warszawie też wiedziano, że w polskich środowiskach demokratycznych w Rosji ujawniły się w $1917 \mathrm{r}$. nadzieje na wypracowanie wspólnej polityki polskiej, takiej która potrafiłaby wznieść się ponad dotychczasowe orientacje. Tego typu współpracę mogli zatem śmiało zaproponować działaczom demokratycznym. Podstawą propozycji TRS było wezwanie do budowy państwowości w Kraju, przy jednoczesnym jak najszerszym umiędzynarodowieniu sprawy polskiej. Zakładała ta propozycja również neutralność wobec toczącego się konfliktu światowego, przy założeniu że zakończy się on w sposób nie rozstrzygnięty. W tej sytuacji o przyszłości Polski zadecydowałby kongres pokojowy, na którym obie wojujące strony uznałyby najprawdopodobniej niepodległościowe aspiracje Polaków. Chcąc zatem wyjść

5 APK NKN, t. XLIV, k. 699

6 Archiwum Akt Nowych. Ministerstwo Spraw Zagranicznych [dalej: AAN MSZ], mkr. 7577 , k. 20. 
z toczącej się wojny jako niepodległe państwo, Polska powinna konsekwentnie trzymać się neutralności. Demokratom tego typu program wyjątkowo odpowiadal.

W wyniku zaktywizowania się po lutowym przewrocie rewolucyjnym politycznych i wojskowych rzeczników tworzenia polskich formacji w Rosji, przed ugrupowaniami demokratycznymi stanął dylemat: sprzeciwić się, czy też poprzeć te dążenia. Wobec reprezentowanej przez demokratów orientacji politycznej sprawa była $w$ istocie $z$ góry przesądzona. Przyjęcie odmiennego stanowiska oznaczałoby przyznanie, że na wychodźstwie też istnieje, lub może powstać, ośrodek władzy politycznej posiadający prerogatywy reprezentacji ogólnokrajowej. Tymczasem demokraci za taki ośrodek władzy uznawali wyłącznie TRS, postrzegając tę instytucję jako najwyższy urząd państwowotwórczy i zaczątek przyszłego rządu polskiego ${ }^{7}$. Zatem tworzenie własnych jednostek na Wschodzie było w ich odczuciu wyłącznie uzależnione od woli Kraju. Wydaje się jednak, że pogląd demokratów na kwestię formowania polskiego wojska w Rosji wynikał nie tyle z przeświadczenia, że aktywiści w Kraju tego sobie nie życzą ${ }^{8}$, ale przede wszystkim z obawy, że nie uda się wygrać rywalizacji z endec ją o polityczne kierownictwo nad tym wojskiem. Skoro zaś nie można było liczyć na objęcie przywództwa nad tymi formacjami, to zamiast o nie walczyć demokraci zdecydowani byli nie dopuścić do ich powstania, co w ich odczuciu ostatecznie załatwiało całą sprawę. Poza tym demokraci, sprzeciwiając się tworzeniu polskiego wojska w Rosji, w swych kalkulacjach brali pod uwage fakt, że ewentualne jego stworzenie będzie równoznaczne $z$ definitywnym przejściem na stronę Ententy, co wobec niepewnego ich zdaniem wyniku wojny było przedwczesne. Mniej natomiast niepokoiło demokratów równie przedwczesne przecież wikłanie się aktywistów w Kraju we współprace przy tworzeniu formacji polskich mających walczyć po stronie państw centralnych.

Do ostatecznego zacieśnienia więzów łączących demokratów z obozem aktywistycznym dojść miało podczas przygotowywanej usilnie przez obie strony, dodajmy nie bez zakulisowego udziału Naczelnego Komitetu Narodowego [dalej: NKN] i dyplomacji austro-węgierskiej, konferencji politycznej w Sztokholmie.

7 Archiwum Akt Nowych. Gabinet Cywilny Rady Regencyjnej [dalej: AAN GCRR], dz. 445/II, t. XXXIV, k. 8.

8 Podczas I Konferencji Sztokholmskiej to demokraci niemal wymusili na delegatach z Kraju deklarację sprzeciwiającą się formowaniu polskiego wojska w Rosji. 


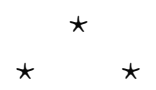

Wiosną 1917 r. wokół sprawy polskiego wojska w Rosji rozgorzała zaciekła batalia, toczona zarówno w środowiskach politycznych polskiego wychodźstwa w Rosji, jak też w kręgu wojskowych Polaków służących w armii rosyjskiej. W jej trakcie ustalił się ostatecznie pogląd poszczególnych grup w odniesieniu do tego zagadnienia. W procesie krystalizacji stanowiska demokratów rolę szczególną odegrała narada zorganizowana w dniach 5-10 maja 1917 r. w Sztokholmie. Jej najpoważniejszą konsekwencją było utrwalenie się w tym obozie politycznym negatywnych ocen koncepcji zorganizowania polskiego wojska w Rosji. W historiografii polskiej poza publikacja Mieczysława Wrzoska ${ }^{9}$ wspomina się o tym wydarzeniu dość rzadko, a jeśli już, to na marginesie rozważań poświęconych innym, szerzej poruszanym kwestiom ${ }^{10}$. W tym miejscu zatem koniecznym staje się podjęcie wysiłku uporządkowania już znanych faktów oraz ustalenia nowych w oparciu o dostępny materiał źródłowy ${ }^{11}$. Pierwszą wzmiankę o zabiegach, które doprowadziły do zorganizowania I Konferencji Sztokholmskiej, zawiera telegram wysłany 3 kwietnia 1917 r. przez posła austro-węgierskiego w Sztokholmie, hrabiego Maksymiliana Hadika von Futak do Stefana von Ugrona ${ }^{12}$ będacego $\mathrm{w}$ tym czasie przedstawicielem wiedeńskiego ministra spraw zagranicznych w Warszawie. We wspomnianym telegramie wyeksponowana jest osoba Stanisława Wędkiewicza. Jak ustalił M. Wrzosek w oparciu o materiały

9 M. Wrzosek, Konferencja Sztokholmska, a sprawa polskiego wojska w Rosji w 1917 roku, w: Pax et bellum, pod red. K. Olejnika, Poznań 1993, s. 311-322.

10 Kwestia wojska polskiego w Rosji w 1917 r., oprac. W. Szczęsny, Warszawa 1936, s. 109-113; L. Grosfeld, Polskie reakcyjne formacje wojskowe w Rosji 1917-1919, Warszawa 1956, s. 18-20; H. Jabłoński, Polityka PPS w czasie wojny 1914-1918, Warszawa 1958, s. 325-328; J. Holzer, J. Molenda, Polska w I wojnie światowej, Warszawa 1973, s. 300; M. Wrzosek, Polskie korpusy wojskowe w Rosji w latach 1917-1918, Warszawa 1969, s. 54-56; tegoz, Polskie formacje wojskowe podczas I wojny światowej, Białystok 1977, s. 207.

11 Doskonałym źródłem pozwalającym rozszerzyć zakres naszej wiedzy na temat tzw. I Konferencji Sztokholmskiej są materiały archiwalne przechowywane w wiedeńskim Haus-Hof- und Staatsarchiv, do których dotarł, opracował i opublikował M. Wrzosek. Patrz tegoż, Problem wojska polskiego w Rosji w latach 1917-1918, „Studia Podlaskie” 1995, t. V.

12 Telegram ambasadora Austro-Węgier hr. M. Hadika von Futak, nr 101 z 3.04.1917 r. do przedstawiciela Austro-Węgier w Warszawie S. von Ugrona o wniosku S. Wędkiewicza w sprawie przyjazdu hr. A. Ronikiera na spotkanie w Sztokholmie z dwoma reprezentantami polskiego wychodźstwa z Piotrogordu, w: M. Wrzosek, Problem wojska..., s. 183; tegoż, Konferencja Sztokholmska..., s. 314. 
archiwalne wiedeńskiego Haus-Hof- und Staatsarchiv, S. Wędkiewcz przebywał wówczas w Sztokholmie jako przedstawiciel NKN i niewykluczone, choć nie udało się tego potwierdzić, iż w sprawach dotyczących konferencji działał w myśl poleceń swoich mocodawców, tj. Władysława Leopolda Jaworskiego, względnie Władysława Sikorskiego ${ }^{13}$. Pewnym jest, że na przełomie marca i kwietnia 1917 r. zaczął podejmować starania o to, aby doprowadzić do spotkania między reprezentantem obozu aktywistycznego z Kongresówki, a dwoma osobami, które miały przybyć z Piotrogrodu i wystąpić w imieniu środowisk zajmujących zbliżone stanowisko polityczne. Rzecz jasna chodziło tu o demokratów i ich sojuszników, choć osoby oczekiwane z Rosji nie zostały wymienione $\mathrm{z}$ nazwiska. Natomiast wspomnianym przedstawicielem aktywistycznych środowisk z Kraju miał być hrabia Adam Ronikier. Hrabia M. Hadik von Futak skierował swój telegram do S. von Ugrona za pośrednictwem austro-węgierskiego ministra spraw zagranicznych [dalej: MSZ], informując adresata ogólnikowo, że rozmowa będzie dotyczyć sprawy uznanej jako ważna. Nadawca telegramu zastrzegł jedynie, iż cel misji hrabiego A. Ronikiera powinien być zatajony przed niemieckim sprzymierzeńcem Austro-Węgier. Zastrzeżenie to miało istotne znaczenie, ponieważ hrabia A. Ronikier był zmuszony do przejazdu przez terytorium państwa niemieckiego w drodze do Sztokholmu.

Treść telegramu hrabiego M. Hadika von Futak wzbudziła głębokie zainteresowanie ministra spraw zagranicznych Austro-Węgier hrabiego Ottokara Czernina, gdyż już 4 kwietnia 1917 r. nadał telegram do swego podwładnego w Sztokholmie, w którym stwierdził m.in. że ma wątpliwości, czy powinno dojść do spotkania między hrabią A. Ronikierem, a wzmiankowanymi Polakami z Piotrogrodu, określonymi tu przez szefa austro-węgierskiej dyplomacji jako Rosjanie, oraz czy sprawa zasługuje na utrzymanie w tajemnicy przed sprzymierzeńcami, skoro cel zapowiadanych rozmów nie jest znany. Na koniec hrabia O. Czernin stwierdził co prawda, że przekaże S. von Ugronowi sztokholmski telegram, ale zanim to nastąpi, chce wiedzieć, jakich spraw będzie dotyczyć spotkanie, o którym jest w nim mowa ${ }^{14}$. Odpowiedź hrabiego M. Hadika von Futak, sformułowana w telegramie z 7 kwietnia 1917 r.,

13 M. Wrzosek, Konferencja Sztokholmska..., s. 313.

14 Telegram nr 111 z 4.04.1917 r. austro-węgierskiego ministra spraw zagranicznych hr. O. Czerina do ambasadora Austro-Węgier w Sztokholmie hr. M. Hadika von Futak, $\mathrm{z}$ obiekcjami dotyczącymi spotkania $\mathrm{w}$ nieznanej sprawie, awizowanego $\mathrm{w}$ telegramie ze Sztokholmu z 3.04.1917 r., w: M. Wrzosek, Problem wojska..., s. 183; tenże, Konferencja Sztokholmska..., s. 314 . 
dotarła do Wiednia następnego dnia ${ }^{15}$, a była oparta na wyczerpującej rozmowie posła austro-węgierskiego w Sztokholmie z S. Wędkiewiczem. Hrabia M. Hadik von Futak informował: „Bei fraglicher Zusammenkunft soll, wie mir Dr Wedkiewicz mitteilt, Moglichkeit besprochen werden, in Russland lebende und auch die emigrierten Polen daran zu verhindern, eine Armee gegen uns zu bilden" ${ }^{16}$.

Przytoczone zdanie określa w sposób jednoznaczny, z czyjej inicjatywy było podjęte przeciwdziałanie tym zabiegom, które miały na celu formowanie polskiego wojska w Rosji. Uzewnętrznia się tu zupełnie niedwuznacznie udział NKN i dyplomacji austro-węgierskiej, co rzuca nowe światło na przebieg walki o polskie wojsko w Rosji. Hrabia M. Hadik von Futak podkreślał dalej, że Polacy poza granicami Austro-Węgier okazują wielki entuzjazm dla rewolucji rosyjskiej, i utrzymywał, że zdaniem S. Wędkiewicza utworzenie polskiego wojska u boku przeciwników monarchii habsburskiej jest bardzo prawdopodobne. Miał się też S. Wędkiewicz wyrazić, że $\mathrm{w}$ interesie Wiednia jest przeciwstawienie się wszelkimi możliwymi sposobami stworzeniu tego wojska. Natomiast swoją prośbę o zachowanie całej sprawy w tajemnicy przed Niemcami uzasadnić miał S. Wędkiewicz nieufnością, jaka się utrzymywała między władzami niemieckimi, a ludnością polską. O wiarygodność hrabiego A. Ronikiera strona austro-węgierska mogła być całkowicie spokojna, tak przynajmniej uważał hrabia M. Hadik von Futak $^{17}$. Wyjaśnienia oparte na sugestiach S. Wędkiewicza przesłane zostały do Wiednia, gdzie spotkały się ze zrozumieniem ministra O. Czernina. Zostały też przekazane do Warszawy wraz z informacją, że przyjazd hrabiego A. Ronikiera do Sztokholmu jest oczekiwany w dniach między 14 a 18 kwietnia 1917 r. O. Czernin powiadamiał S. von Ugrona, że zmiana zaproponowanego terminu jest możliwa, ale gdyby do tego doszło, wiadomość dotycząca tej zmiany powinna być skierowana do Sztokholmu niezwłocz-

15 Telegram nr 115 z 7.04.1917 r. ambasadora austro-węgierskiego hr. M. Hadika von Futak w odpowiedzi na telegram nr 111 austro-węgierskiego ministra spraw zagranicznych hr. O. Czernina z wyjaśnieniem, że planowane spotkanie ma dotyczyć sprawy polskiego wojska w Rosji, w: M. Wrzosek, Problem wojska..., s. 184; tenże, Konferencja Sztokholmska..., s. 14.

16 W branym pod uwage spotkaniu, jak mnie poinformował dr Wędkiewicz, powinna być omówiona sprawa, jak Polakom żyjącym w Rosji i przebywającym tam na emigracji przeszkodzić w utworzeniu wrogiej nam armii. Patrz: Telegram nr 115 z 7.04.1917 r. j.w.

17 Telegram nr 115 z 7.04.1917 r., j.w.; M. Wrzosek, Konferencja Sztokholmska..., s. 314 . 
nie $^{18}$. Wstępną wymianę korespondencji zakończyła depesza S. von Ugrona, który 11 kwietnia 1917 r. poinformował ministra O. Czernina, że hrabia A. Ronikier przyjął powierzoną mu misję i rozpoczął przygotowania do podróży. Okazało się przy tym, że polski wysłannik wyrażał pragnienie, aby w rozmowach towarzyszyła mu jeszcze jakaś osoba. Dobór tej osoby miał być dopiero przedmiotem negocjacji, ale S. von Ugron brał tylko pod uwagę możliwość wyboru dyrektora Departamentu Spraw Ogólnych TRS, hrabiego Wojciecha Rostworowskiego, względnie marszałka koronnego Wacława Niemojowskiego, jako współtowarzysza podróży hrabiego A. Ronikiera ${ }^{19}$.

Z ustaleń M. Wrzoska opartych na szczegółowej analizie tej korespondencji, która między 3 a 13 kwietnia 1917 r. krążyła między Sztokholmem, Wiedniem i Warszawą, wynika, że zasadnicze motywy, jakimi się powodowały osoby zaangażowane w przygotowanie I Konferencji Sztokholmskiej, wynikały nie $z$ dążeń do uzgodnienia stanowisk politycznych pomiędzy TRS i przedstawicielami proaktywistycznych ugrupowań polskich w Rosji, ani też z wysiłków na rzecz ustalenia wspólnej taktyki przedstawicieli tych środowisk, lecz $z$ poważnej obawy o interesy monarchii naddunajskiej $\mathrm{i}$ tych środowisk polskich, które $\mathrm{z}$ nią wiązały nadzieje na rozwiązanie sprawy polskiej. Interesy obu stron zostałyby poważnie zagrożone, gdyby doszło do powstania polskiego wojska w Rosji. Realna możliwość powstania takiego wojska, w odczuciu zarówno dyplomacji austro-węgierskiej, jak też i polskich aktywistów, stała się jeszcze bardziej prawdopodobna, gdy do Wiednia dotarła alarmistyczna depesza hrabiego Dionizego Szechenyego. Depesza została nadana z Kopenhagi 12 kwietnia 1917 r., a więc już po wstępnych ustaleniach odnośnie uzgodnionego spotkania w Sztokholmie. Poseł austro-węgierski w Danii donosił w niej o przygotowaniach do tworzenia odrębnych polskich korpusów wojskowych w sile 250 tysięcy żołnierzy. Wzmiankował ponadto o poleceniu wydanym jakoby dowódcom poszczególnych armii rosyjskich w sprawie koncentrowania wojskowych Polaków w specjalnie wyznaczonych miejscach. Poza tym depesza hrabiego D. Szechenyego wspominała

18 Telegram nr 69 z 9.04.1917 r. austro-węgierskiego ministra spraw zagranicznych hr. O. Czernina do przedstawiciela Austro-Węgier w Warszawie S. von Ugrona z wyjaśnieniem, iz powinno to spotkanie być utrzymane w ścisłej tajemnicy przed stroną niemiecką, w: M. Wrzosek, Problem wojska..., s. 185.

19 Telegram nr 200 z 11.04 .1917 r. austro-węgierskiego przedstawiciela w Warszawie hr. S. von Ugrona z odpowiedzią na telegram nr 69 z 9.04.1917 r. austro-węgierskiego ministra spraw zagranicznych hr. O. Czernina, informujący o zgodzie hr. A. Ronikiera na wyjazd do Sztokholmu i o jego prośbie w sprawie wydelegowania towarzyszącej mu osoby z grona członków TRS, w: M. Wrzosek, Problem wojska..., s. 185-186. 
o nieufności rosy jskiego Rządu Tymczasowego do własnych żołnierzy i o rzekomym zamiarze wysuwania polskich formacji wojskowych na szczególnie ważne odcinki frontu. Na podstawie tych wszystkich faktów, o których sam wspomniał w kopenhaskiej depeszy, hrabia D. Szecheny wnioskował nawet, że Rosja zamierza kształtować trzon przyszłej armii polskiej ${ }^{20}$. Wniosek ten, rzecz zrozumiała, wzbudził wyraźne zaniepokojenie austro-węgierskich czynników rządowych, którego jednakże nie podzielały kręgi wojskowe, o czym świadczy odręczna uwaga jaką na marginesie depeszy sformułował niejaki płk Zeynek, a brzmi ona: „Die Nachricht, was der angebrachten Zahlen betrifft ganz unwahrscheilich" 21.

W dniu 13 kwietnia 1917 r. nastąpił wyjazd hrabiego A. Ronikiera z Warszawy do Sztokholmu. Jego współtowarzyszem, wbrew pierwotnym propozycjom, był dyrektor Departamentu Pracy TRS Włodzimierz Kunowski. Chęć wyjazdu zgłosił również książę Zdzisław Lubomirski, ale spotkała się ona $\mathrm{z}$ odmową austro-węgierskiego przedstawicielstwa $\mathrm{w}$ Warszawie ${ }^{22}$. Hrabia A. Ronikier został upoważniony do zatrzymania się w Berlinie podczas podróży w obie strony i do złożenia wizyty podsekretarzowi stanu w niemieckim MSZ Arturowi Zimmermannowi. W razie uzyskania jakichś ważnych informacji miał się udać z Berlina do Wiednia i dopiero później wyruszyć do Sztokholmu ${ }^{23}$. O wyjeździe hrabiego A. Ronikiera i W. Kunowskiego z Warszawy do Sztokholmu został powiadomiony austro-węgierski poseł w Szwecji hrabia M. Hadik von Futak, a za jego pośrednictwem przekazano tę wiadomość S. Wędkiewiczowi ${ }^{24}$. W tym czasie, gdy delegacja prze-

20 Telegram nr 178 z 12.04.1917 r. austro-węgierskiego posła w Danii hr. D. Szechenyego do austro-węgierskiego ministra spraw zagranicznych hr. O. Czernina o rzekomych decyzjach podjętych w Rosji w sprawie utworzenia tam 250-tysięcznego polskiego wojska, w: M. Wrzosek, Problem wojska..., s. 186; tenże, Konferencja Sztokholmska..., s. 316.

21 Wiadomość odnosząca się do podanej liczby jest zupełnie nieprawdopodobna.

22 Telegram nr 204 z 13.04.1917 r. austro-węgierskiego przedstawiciela w Warszawie hr. S. von Ugrona do austro-węgierskiego ministra spraw zagranicznych hr. O. Czernina informujący o wy jeździe do Sztokholmu hr. A. Ronikiera i W. Kunowskiego oraz odrzuceniu prośby ks. Z. Lubomirskiego dołączenia go do tej delegacji, w: M. Wrzosek, Problem wojska.., s. 187; tenże, Konferencja Sztokholmska..., s. 316.

23 Telegram nr 206 z 13.04.1917 r. uzupełniający depeszę nr 204 i zawierający informację o zamierzonej rozmowie hr. A. Ronikiera $\mathrm{z}$ niemieckim podsekretarzem w Ministerstwie Spraw Zagranicznych A. Zimmermannem, w: M. Wrzosek, Problem wojska..., s. 187; tenże, Konferencja Sztokholmska..., s. 316.

24 Telegram nr 136 z 14.04.1917 r. austro-węgierskiego ministra spraw zagranicznych hr. O. Czernina do austro-węgierskiego ambasadora w Sztokholmie hr. M. Hadika von Futak z powiadomieniem o wyjeździe hr. A. Ronikiera i W. Kunowskiego do Sztokholmu, w: M. Wrzosek, Problem wojska..., s. 188; tenże, Konferencja Sztokholmska..., s. 317. 
bywała już w Sztokholmie, minister O. Czernin otrzymywał dalsze depesze od hrabiego D. Szechenyego. Na uwagę zasługuje jedna spośród tych depesz, a mianowicie z 23 kwietnia 1917 r., w której austro-węgierski dyplomata informował z Kopenhagi, powołu jąc się na wydawaną w Moskwie „Gazetę Polską", o ważnej naradzie oficerów polskich, którzy podjęli uchwałę w sprawie tworzenia w Rosji silnego, polskiego korpusu wojskowego ${ }^{25}$. Chodzi tu albo o wspólną naradę przedstawicieli piotrogrodzkiego i moskiewskiego Związku Wojskowych Polaków [dalej: ZWP], która odbyła się 9 września 1917 r. w Moskwie, względnie o zjazd wojskowych Polaków rosyjskiej V Armii. Ten ostatni odbywał się w Rzeżycy w dniach 10-16 kwietnia 1917 r. Sygnały dochodzące z Kopenhagi wpłynęły z pewnością na przyśpieszenie przygotowań do projektowanej I Konferencji Sztokholmskiej. Delegacja aktywistów z Kongresówki dotarła do Sztokholmu 18 kwietnia 1917 r. i w stolicy Szwecji zastała J. Ziabickiego z Piotrogrodu, który wywodził się ze środowiska przemysłowców polskich i należał do PZN. Istotne znaczenie dla jego obecności miało zwłaszcza to, że był on w bliskich stosunkach $\mathrm{z}$ mecenasem A. Lednickim stojącym na czele KLdSKP ${ }^{26}$. Jednakże spotkanie z J. Ziabickim nie wywarło wyraźnego wpływu na przyśpieszenie przygotowań do projektowanej konferencji. Delegat demokratów z Piotrogrodu zobowiązał się wprawdzie do przekazania zaproszeń dla kilku osób, których grono zostało zapewne ustalone przy jego współudziale, ale przybycie wytypowanych działaczy ze stolicy Rosji do Sztokholmu nie mogło nastąpić dostatecznie szybko. Nastąpiła więc niespodziewana zwłoka i spowodowała ona zniecierpliwienie środowisk aktywistycznych w Warszawie. Wyraźnie dostrzegalne jest to w depeszy przesłanej do Sztokholmu przez hrabiego W. Rostworowskiego, który dopytywał się o wyniki rozmów i o termin ewentualnego powrotu hrabiego A. Ronikiera ${ }^{27}$. Decyzje dotyczące tego powrotu zapadły w okolicznościach uwarunkowanych nie tylko nieobecnością w Sztokholmie przedstawicieli polskich środowisk proaktywistycznych z Rosji, lecz także w związku z przystąpieniem Austro-Węgier do szeroko zakrojonej akcji propagandowej na rzecz pokoju. Akcja ta była projektowana $z$ inicja-

25 Telegram nr 211 z 23.04.1917 r. austro-węgierskiego posła w Danii hr. D. Szechenyego do austro-węgierskiego ministra spraw zagranicznych hr. O. Czernina o rzekomej uchwale wojskowych Polaków w sprawie tworzenia polskiego korpusu wojskowego, w: M. Wrzosek, Problem wojska..., s. 188; tenże, Konferencja Sztokholmska..., s. 317.

26 Szerzej o KLdSKP pisze M. Wrzosek, Pierwsze sprawozdanie z działalności KLdSKP, „Teki Archiwalne”, t. VIII, Warszawa 1961, passim.

27 M. Wrzosek, Konferencja Sztokholmska..., s. 317--318. 
tywy posła austro-węgierskiego w Szwecji hrabiego M. Hadika von Futak, który brał pod uwagę konieczność neutralizacji wysiłków dyplomatycznych Wielkiej Brytanii i Francji na rzecz utrzymania Rosji w gronie państw koalicji. Hrabia A. Ronikier ruszył więc w drogę powrotną i miał wystąpić wobec wpływowych czynników austro-węgierskich jako orędownik zamierzonej akcji propagandowej ${ }^{28}$. Informację o przedwczesnym powrocie hrabiego A. Ronikiera ze Sztokholmu zawiera również depesza przesłana ministrowi O. Czerninowi przez hrabiego S. von Ugrona, który ponadto wzmiankował w niej o nagłym wyjeździe hrabiego W. Rostworowskiego do Berlina. Decydując się na ten wyjazd, dyrektor Departamentu Spraw Ogólnych TRS spodziewał się, że otrzyma od hrabiego A. Ronikiera jakieś ważne informacje i liczył ponadto na przeprowadzenie interesujących rozmów z przedstawicielami berlińskich kół kierowniczych ${ }^{29}$. Powrót hrabiego A. Ronikiera do Warszawy nastąpił 7 maja 1917 r., a wzmiankuje o tym telegram hrabiego S. von Ugrona z 8 maja 1917 r., który nie zawiera jednak żadnych wy jaśnień, gdzie delegat Kongresówki przebywał w okresie od 30 kwietnia do 7 maja 1917 r. Najprawdopodobniej był w Wiedniu na konsultacjach w sprawie wzmiankowanej powyżej inicjatywy hrabiego M. Hadika von Futak. Nie ma też informacji, jak doszło do tego, że to hrabia W. Rostworowski znalazł się niebawem w Sztokholmie jako delegat TRS ${ }^{30}$. Wydaje się, iż zaangażowanie hrabiego A. Ronikiera w promocję pomysłu posła austro-węgierskiego w Sztokholmie, by zorganizować akcję propagandową na rzecz pokoju, uniemożliwiło kontynuację pierwotnej misji. Zatem w trakcie berlińskiego spotkania obu naszych rodaków, niedoszły delegat TRS na konferencję wprowadził w szczegóły sztokholmskiej misji hrabiego W. Rostworowskiego i wysłał w zastępstwie na rozmowy z polskimi politykami z Rosji.

28 Telegram nr 179 z 25.04 .1917 r. austro-węgierskiego ambasadora w Szwecji hr. M. Hadika von Futak do austro-węgierskiego ministra spraw zagranicznych hr. O. Czernina $\mathrm{z}$ postulatem neutralizowania nacisków Ententy na Rosję w celu utrzymania tego państwa jako aktywnego uczestnika Koalicji, w: M. Wrzosek, Problem wojska..., s. 189; tenże, Konferencja Sztokholmska..., s. 318.

29 Telegram nr 256 z 30.04.1917 r. austro-węgierskiego przedstawiciela w Warszawie hr. S. von Ugrona do austro-węgierskiego ministra spraw zagranicznych hr. O. Czernina z informacją o mającym nastapić w Berlinie spotkaniu hr. W. Rostworowskiego z hr. A. Ronikierem, w: M. Wrzosek, Problem wojska..., s. 191; tenże, Konferencja Sztokholmska..., s. 318 .

30 Telegram n r 283 z 8.05.1917 r. austro-węgierskiego przedstawiciela w Warszawie hr. S. von Ugrona do austro-węgierskiego ministra spraw zagranicznych hr. O. Czernina w sprawach dotyczących TRS, regencji w Królestwie Polskim i polskiego wojska w Rosji, w: M. Wrzosek, Problem wojska..., s. 192; tenże, Konferencja Sztokholmska..., s. 318. 
Pierwsza Konferencja Sztokholmska rozpoczęła się 5 maja 1917 r. i trwała, jak już wspomniałem, do 10 maja. Ustalenia jakie poczynił w swoim artykule M. Wrzosek dają podstawę, aby sprostować informację zawartą w opracowaniu przygotowanym przez W. Szczęsnego, w którym ten ostatni stwierdza, że „Konferencja została zwołana z inicjatywy przedstawicieli obozu niepodległościowego w Rosji" ${ }^{31}$. W gronie krajowych uczestników spotkania sztokholmskiego, obok W. Kunowskiego i hrabiego W. Rostworowskiego, znaleźli się S. Wędkiewicz i książę Ksawery Drucki-Lubecki z zaboru pruskiego ${ }^{32}$. W skład delegacji z Rosji, która przybyła do Sztokholmu dopiero w pierwszych dniach maja 1917 r., wchodzili: Franciszek Skąpski reprezentujący POW, Bronisław Siwik jako przedstawiciel PPS-FR, a także Hipolit Gliwic, Stefan Filipkowski, Aleksander Babiański i J. Ziabicki, którzy reprezentowali zarówno PZN, jak i Polski Komitet Demokratyczny [dalej: PKD]. Działaczom przybyłym z Piotrogrodu towarzyszył w charakterze gościa przedstawiciel Stronnictwa Polityki Realnej [dalej: SPR], Ignacy Szebeko, uczestniczący w trakcie konferencji w rozmowach nieoficjalnych. W oficjalnej części I Konferencji Sztokholmskiej brali też udział przedstawiciele Komitetu Obrony Narodowej [dalej: KON] ze Stanów Zjednoczonych ${ }^{33}$ - Aleksander Dębski i Józef Karasiewicz, a także prezes Komitetu Polskiego w Sztokholmie Wacław Dzierżawski oraz kierownik polskiej agencji prasowej w Sztokholmie Józef Mokrzyński ${ }^{34}$. Oprócz konferencji właściwej toczyły się nieoficjalne, blisko dwutygodniowe rozmowy, w których brał udział, jak już wspomniałem, I. Szebeko oraz przedstawiciele endecji, a mianowicie Stanisław Kozicki, hrabia Władysław Sobański i Eustachy Dobiecki35.

Podczas obrad I Konferencji Sztokholmskiej nastąpiła wymiana wiadomości o sytuacji w Kraju i w Rosji. Jak ustalił w toku swych badań M. Wrzosek, istniejące przesłanki źródłowe wskazują na to, że przedstawiciele TRS nie uzyskali obiektywnego obrazu sytuacji w sprawach związanych z rozmiarami żywiołowego polskiego ruchu wojskowego. Rozmiary tego ruchu pomniejszał i bagatelizował nawet I. Szebeko, który być może chciał

31 Kwestia wojska..., s. 109.

32 M. Wrzosek, Polskie kor pusy..., s. 54.

33 Komitet Obrony Narodowej został zorganizowany w grudniu 1912 r. w Stanach Zjednoczonych, a jego naczelnym hasłem było popieranie wszelkich inicjatyw przeciwko Rosji, którą uznano za. największego wroga. Polski. Naturalną konsekwencją powyższego stanowiska było nawiązanie przez KON w trakcie wojny współpracy ze środowiskiem aktywistycznym w Kraju i Europie Zachodniej.

34 Kwestia wojska..., s. 109-113.

35 H. Jabłoński, op. cit., s. 326; M. Wrzosek, Konferencja Sztokholmska..,, s. 319. 
się dostroić do tonu tych informacji, jakich udzielali przedstawicielom TRS poplecznicy polskiego aktywizmu na gruncie rosyjskim. I. Szebeko wyraził nawet opinię, że jeden korpus byłby w stanie ująć cały ten ruch w ścisłe ramy organizacyjne. Osąd ten nie odpowiadał ówczesnej postawie wojskowych Polaków w Rosji, co uzewnętrzniają nawet przekazy czerpane $\mathrm{z}$ akt NKN odzwierciedlające ówczesny stan wiedzy aktywistów na ten temat ${ }^{36}$. Wypowiedzi I. Szebeki towarzyszyło stwierdzenie któregoś z przedstawicieli TRS, najprawdopodobniej hrabiego W. Rostworowskiego: „Jeżeli wśród żołnierzy Polaków jest chęć do tworzenia własnych szeregów, to niech formują korpus" ${ }^{37}$. Wskazywałoby to, że hrabia W. Rostworowski nie chciał się przeciwstawić idei polskiego wojska w Rosji w sposób zdecydowany. W tym miejscu drobna dygresja, otóż warto zwrócić uwagę, że część działaczy TRS najwyraźniej nie podzielała, ani obaw swoich współpracowników, ani obaw większości działaczy NKN dostrzegających w pomyśle zorganizowania polskiego wojska na wschodzie zagrożenie dla sprawy polskiej. Przytoczona wersję dyskusji w trakcie I Konferencji Sztokholmskiej podaje J. Marcińczyk, opierając się na wypowiedzi A. Babiańskiego, który po powrocie ze stolicy Szwecji składał sprawozdanie na wiecu zorganizowanym w piotrogrodzkiej sali klubu „Ogniwo”. Wersja J. Marcińczyka może być prawdziwa, gdyż znajduje potwierdzenie w zeznaniach złożonych przez hrabiego W. Rostworowskiego w 1924 r. podczas rozprawy sądowej wytoczonej Zygmuntowi Wasilewskiemu przez A. Lednickiego. Hrabia W. Rostworowski stwierdził wówczas, że TRS wprawdzie od początku stała konsekwentnie na stanowisku przeciwnym formowaniu w Rosji polskiego wojska opartego na statusie armii sprzymierzonej, ale dodał, że brano też pod uwagę dążenie Polaków do wydostania się z szeregów armii rosyjskiej i nie sprzeciwiano się powołaniu jakiejś, nawet dość dużej formacji polskiej. Podkreślił jednocześnie, że właśnie w tym punkcie delegaci TRS nie zgadzali się z ugrupowaniami demokratycznymi i ich sojusznikami w Rosji, stojącymi na stanowisku całkowicie niechętnym idei polskiego wojska. Potwierdza to w pewnym stopniu jeszcze inna wypowiedź hrabiego W. Rostworowskiego z 31 maja $1917 \mathrm{r}$. złożona na poufnym posiedzeniu TRS, gdy przedstawiał on sprawozdanie z obrad I Konferencji Sztokholmskiej ${ }^{38}$. Na stronę tych uczestników konferencji, którzy przybyli z Rosji, przechylił się natomiast W. Kunowski. On też

36 APK NKN, t. XLIV, s. 87.

37 J. Marcińczyk, Chwila osobliwa, Lublin 1919, s. 114.

38 Materiaty archiwalne do historii stosunków polsko-radzieckich, t. I: marzec 1917 listopad 1918, Warszawa 1957, s. 52. 
sformułował wniosek zawierający wezwanie wychodźstwa polskiego w Rosji do zwalczania wszelkiej myśli o tworzeniu jakichkolwiek oddziałów polskich po stronie Ententy ${ }^{39}$.

Na I Konferencji Sztokholmskiej zwyciężyło ostatecznie stanowisko przeciwników idei polskiego wojska w Rosji, co znalazło swój wyraz w uchwałach końcowych. Uchwały te zaaprobowane jednomyślnie i podpisane przez hrabiego W. Rostworowskiego, W. Kunowskiego, A. Babiańskiego, H. Gliwca, S. Filipkowskiego, A. Dębskiego i J. Karasiewicza, stwierdzają w odniesieniu do sprawy polskiego wojska w Rosji, iż: „(...) konferencja uważa tworzenie wojska i oddziałów polskich, wyodrębnionych z armii rosyjskiej, za szkodliwe dla politycznych interesów państwa polskiego i wzywa do energicznego przeciwdziałania akcji prowadzonej w tym kierunku przez nieodpowiedzialne grupy polityczne na emigracji" ${ }^{40}$. Ten właśnie punkt uchwał sztokholmskich był wkrótce w Rosji najmocniej nagłośniony, stanowiąc ważki argument, którym szachowano zwolenników rozbudowy polskiego wojska. Dalszy rozwój wydarzeń, co zostanie wykazane poniżej, dowiódł, że uchwały sztokholmskie oznaczały fatalny błąd. Polacy służący w armii rosyjskiej na wieść o treści tych uchwał utracili swój pierwotny zapał, popadli w apatię i zostali owładnięci wszechobecną nadzieją demobilizacji i powrotu do domu.

Przełomowym momentem w procesie kształtowania się stanowiska ugrupowań demokratycznych w sprawie polskiego wojska w Rosji był zwołany w dniach 9-10 maja 1917 r. w Moskwie I Zjazd Demokracji Polskiej. Wedle opinii demokratów, wyrażonej w specjalnej Uchwale $w$ sprawie armii polskiej, polityczne kręgi polskie w Rosji powinny uznać, iż „Armia polska powstać może jedynie $\mathrm{z}$ woli narodu pod rozkazami rządu polskiego". Natomiast w danej sytuacji „Ani emigracja, ani wojskowi Polacy nie mają prawa samodzielnie bez porozumienia z Krajem decydować o tworzeniu w szeregach rosyjskich odrębnych formacji wojskowych polskich". Żywiołowy ruch wojskowych Polaków powinien natomiast ograniczyć się w swych poczynaniach, wedle demokratów do „(...) pracy kulturalno-oświatowej i narodowej” 41.

39 A PK NKN, t. XLIV, s. 86; M. Wrzosek, Polskie korpusy..., s. 56; tenże, Kóonferencja Sztokholmska..., s. 320; M. Seyda, Polska na przełomie dziejów. Fakty i dokumenty, Poznań 1931, t. II, s. $144 \mathrm{n}$.

40 Uchwały I Konferencji Sztokholmskiej, w: M. Wrzosek, Konferencja Sztokholmska..., s. 321-322; Kwestia wojska..., s. 111; Materiały archiwalne..., s. 55.

41 Kwestia wojska..., s. 82-83. 
Stanowisko demokratów przedstawione w uchwale zjazdu, znalazło swój wyraz również w poczynaniach poszczególnych odłamów środowiska demokratycznego. W kwestii formowania polskiego wojska poszczególne grupy demokratów okazały się tak bezkompromisowe, że już z góry potępiały wszelkie ewentualne rokowania i zabiegi u władz rosyjskich, podejmowane w tej sprawie przez rzeczników tworzenia narodowych formacji ${ }^{42}$. Pogląd demokratów na kwestię formowania polskiego wojska w Rosji wynikał nie tyle z przeświadczenia, że aktualnie TRS wojska tego sobie nie życzy. Chodziło tu raczej o coś innego. Na tę kwestię tylko w oficjalnych enuncjacjach kładziono specjalny nacisk, faktycznie zaś negatywne stanowisko w odniesieniu do samej idei wynikało z obawy, że SND zmierzać będzie do przekształcenia tego wojska w czynnik swej dominacji na obczyźnie, a następnie w narzędzie swej władzy w Kraju ${ }^{43}$. Obawiali się także demokraci, że zorganizowanie polskiego wojska w Rosji będzie równoznaczne $z$ definitywnym przejściem na stronę Ententy, co wobec niepewnego, ich zdaniem, wyniku wojny było jeszcze zbyt wczesne ${ }^{44}$. Poza tym wskazywali, że doprowadzi to do zmniejszenia siły bojowej armii rosyjskiej. Obawiali się też, że oddziały polskie będą kierowane na niebezpieczne odcinki frontu i zostaną w związku z tym narażone na wielkie straty ${ }^{45}$. Ponadto przestrzegali, że formacje polskiego wojska moga być użyte jako tzw. bataliony szturmowe. Nie bez słuszności, ale i nie bez hipokryzji wspominali wreszcie o negatywnym stosunku Rządu Tymczasowego do sprawy formowania polskiego wojska. Na zmianę stanowiska ugrupowań demokratycznych w odniesieniu do omawianej kwestii mogła wpłynąć chyba tylko perspektywa jakichś wyjątkowych korzyści dla nich samych wynikających $z$ istnienia polskich formacji w Rosji. O trwaniu demokratów na dotychczasowych pozycjach przesądzał zatem fakt, iż żadnych realnych korzyści dla siebie $z$ istnienia tych formacji nie dostrzegali nawet w najdalszej perspektywie. Spostrzegali natomiast już wtedy, że wojskowi Polacy ulegają wpływom pogłębiającej się rewolucji. W związku z powyższym podnosili dodatkowo obawy, że utworzone wojsko ulegnie bolszewizacji. Z lękami tymi nie ujawniali się jednakże oficjalnie, ponieważ liczyli się $\mathrm{z}$ pozytywnym stosunkiem żołnierza polskiego do haseł rewolucyjnych,

42 Kwestia wojska..., s. 83-86.

43 Wypowiedź J. Łukaszewicza, w: K'westia wojska..., s. 63; M. Wrzosek, Polskie korpusy..., s. 47.

44 AAN, Akta Żeligowskiego, t. VIII, s. 18.

45 AAN, Akta Żeligowskiego, t. VIII, s. 14; „Z dokumentów chwili”, z. 56 z 4.09. 1917 r., s. 18 n. 
a chodziło przecież o utrzymanie własnych wpływów w tym środowisku. Chcąc pogodzić ogień $\mathrm{z}$ wodą, tj. zatrzymać Polaków w szeregach armii rosy jskiej i jednocześnie uchronić ich przed bolszewizacją, poszukiwano złotego środka, przy pomocy którego udałoby się osiągnąć jedno i drugie. Dostrzeżono go zwłaszcza w działalności kulturalno-oświatowej ZWP, na co położono nacisk w uchwałach zjazdowych.

Prócz określenia wspólnych dla całego ruchu demokratycznego podstaw ideowoprogramowych, szczególnie jednoznacznych w odniesieniu do kwestii polskiego wojska w Rosji, w trakcie zjazdu wyłoniono swego rodzaju organ kierowniczy dla ogółu ugrupowań demokratycznych, w postaci Komitetu Demokratycznego. W jego składzie nie znalazł się jednak lider moskiewskich demokratów A. Lednicki. Wziął on co prawda udział w zjeździe, a jego bliski współpracownik, Feliks Kierski, wygłosił nawet w imieniu swego mocodawcy referat ogólnopolityczny, niemniej A. Lednicki jako prezes KLdSKP nie wiązał się oficjalnie $z$ ruchem demokratycznym, który po zjeździe został zdominowany przez polityków z ośrodka piotrogrodzkiego. Pomimo kreowania się na apolitycznego przywódcę wychodźstwa polskiego w Rosji, A. Lednicki zasadniczo posiadał, jeśli nie zbieżne, to przynajmniej zbliżone poglądy do całości środowiska, z którego się wywodził. Tym, co go wyróżniało na tle większości współtowarzyszy, był koncyliaryzm. Gwoli prawdy historycznej dopowiedzieć wszakże należy, iż ta postawa bynajmniej nie była bezinteresowna, stanowiła bowiem, jak się wydaje, swego rodzaju rękojmię powodzenia działań A. Lednickiego zmierzających do uzyskania uznania własnej osoby za rzeczywistego lidera polskiej diaspory w Rosji. Faktem pozostaje, iż podobnie jak jego polityczni stronnicy z ugrupowań demokratycznych jedynie Krajowi przyznawał decydującą rolę w rozstrzyganiu jakichkolwiek kwestii politycznych, do których niewątpliwie przede wszystkim należała sprawa polskiego wojska w Rosji. W odniesieniu do tego zagadnienia, podobnie jak delegaci na I Zjazd Demokracji Polskiej w Moskwie, uważał, iż organizowanie polskiego wojska będzie równoznaczne $z$ przejściem na stronę Ententy, co jego zdaniem było jeszcze przedwczesne. Obawie tej A. Lednicki dał wyraz w jednym ze swych przemówień, wygłoszonym już po zjeździe demokratycznym, a tuż przed Ogólnym Zjazdem Wojskowych Polaków. Powiedział wówczas m.in. „(...) cele i zadania tej armii [mowa o polskim wojsku w Rosji - dop. A.M.] niewątpliwie leżą w interesie tych koalicyjnych czynników, które obłudnie i egoistycznie traktują sprawę polską, a w interesie Polski wszakże one nie leżą (...), należy więc zdecydowanie przeciwdziałać tworzeniu się wydzielanych $\mathrm{z}$ rosyjskich związków taktycznych korpusów armii polskiej, mających wykrwawić się w bratobójczej walce w interesie 
koalicji" 46 . Słowa te nie przeszły bez echa w koalicyjnych, głównie brytyjskich, kołach rządowych, w których poczęto z dużą nieufnością i obawami spoglądać na polityczną aktywność samego A. Lednickiego, jak też środowiska politycznego, z którym wbrew oficjalnym zapewnieniom wciąż był ideowo związany. W Londynie i Paryżu uważano odtąd, że działalność A. Lednickiego i Komitetu Demokratycznego w rzeczywistości zmierza do popierania rozwiązania austro-polskiego kwestii polskiej. W praktyce była to konstatacja ze wszech miar słuszna, jak inaczej bowiem można interpretować uchwały I Zjazdu Demokracji Polskiej oraz odbywającej się równolegle I Konferencji Sztokholmṣkiej?

Oba te wydarzenia, a zwłaszcza to co nastąpiło w ich wyniku na gruncie rosyjskim w środowisku wychodźstwa polskiego, szczególnie w odniesieniu do zagadnienia polskiego wojska, w sposób jaskrawy dowodzą, iż ugrupowania demokratyczne zdecydowanie opowiedziały się za aktywistycznym rozwiązaniem kwestii polskiej. Pozostaje sprawą sporną, czy ów aktywizm demokratów polskich w Rosji był tożsamy z germanofilizmem, o co oskarżała to środowisko endecja? Odpowiedzi na to pytanie próżno jednak szukać w uchwałach I Zjazdu Demokracji Polskiej, czy nawet I Konferencji Sztokholmskiej. Pewne przesłanki potwierdzające to podejrzenie są dostrzegalne w działaniach przygotowawczych do I Konferencji Sztokholmskiej, w której wziął udział NKN, dyplomacja austro-węgierska oraz reprezentant ugrupowań demokratycznych z Rosji J. Ziabicki.

46 „Z dokumentów chwili”, z. 44 z 28.06.1917 r., s. 48. 